\title{
EVALUATING THE IMPACT OF POLICY CERTAINTY AND VIOLENCE ON MEDIA COVERAGE OF THE U.S WITHDRAWAL FROM AFGHANISTAN AND RE- EMERGENCE OF TALIBAN: COMPARATIVE ANALYSIS OF NEW YORK TIMES, THE NEWS AND OUTLOOK AFGHANISTAN
}

\author{
Jamal Ud Din \\ Assistant Professor \\ Department of Media \& Communication Studies \\ University of Swat \\ Pakistan \\ jamaluddin@uswat.edu.pk \\ Latif Ahmad \\ Graduate of the Department of Media \& Communication Studies \\ University of Swat \\ Pakistan \\ ahmad12.jmc@gmail.com \\ Rafi Ullah \\ Lecturer \\ Department of Media \& Communication Studies \\ University of Swat \\ Pakistan \\ rafiullah@uswat.edu.pk
}

\begin{abstract}
This article examines the nature of cross-national media coverage of two selected issues including the U.S forces' withdrawal and re-emergence of Taliban in the context of foreign policy. Testing the Bennet (1990) indexing theory and Pier Robins $(2000,2017)$ media-policy interaction model, the study contently analyzes the news coverage of daily newspapers i.e. Outlook Afghanistan, The News and New York Times on selected issues, with a major aim to evaluate the nature of media coverage on the basis of policy certainty [certain or uncertain policy line of governments of Afghanistan, Pakistan and the United States on the issue re-emergence
\end{abstract}






of Taliban and the U.S withdrawal]. The findings of this study show significant policy uncertainty, leading media to criticize Taliban and the U.S in the context of re-emergence of Talibanization in Afghanistan. Whereas the findings also confirm the key arguments of indexing theory as all the selected media, comparatively, framed high the U.S officials and Taliban, who dominate both the issues as key actors. Overall results indicate mixed approach of the selected media as Pakistani newspaper is found adopting a 'balance approach' that indicates Pakistan's policy towards changing political environment in Afghanistan while the Outlook Afghanistan and New York Times were more supportive to the U.S forces withdrawal, however criticized the re-emergence of Taliban.

Keywords: The U.S withdrawal, Taliban, Talibanization, policy uncertainty, capturing

\section{Introduction}

Studying the relationship between media and government is in area of interest for many scholars in the field of political communication including Althaus, 2003; Bennett, 2003; Entman, 2003; Lawrence, 2000 and Robinson, 2000. They studied the state of relationship between media and government, mainly, in the context of policy issues. It is a debate among academia and researchers that most of the available scholarship in the field of political communication evaluates the relationship between media and western government[s], whereas the media, reportedly, take the policy guidelines of government into consideration when they [media] report any policy issue. Hence, focusing on the western democratic system, researchers such as Hallin, 1986; Robinson, 2000 \& 2001 evaluate the role of media during humanitarian crisis and interventions, especially the U.S intervention in Latin America, Middle East and Southeast Asia- Vietnam. However, it is not true in all cases that the media will follow the policy guidelines of [western] governments as the canon of journalism and the freedom of press guide the media to generate a critical narrative too, predominantly, the disagreement among elites on any policy issue (Bennett, 1990) provide media an opportunity to frame that particular foreign policy issue or event critically. For instance, the New York Times opposed the U.S. foreign policy towards Pakistan (Banyan, 2012), which was shaped and adopted in the context of war on terror.

Discussing the media role both critically and supportive to government's policy line, the available scholarship indicates that from the Somalia intervention to the wars in Iraq and Afghanistan, the media has largely backed policymakers who are jingoistic and militaristic. In Rwanda, the media publicly advocated for the assassination of the "opponents." labelling them a national security danger (Youngblood. 2012). Similarly, 


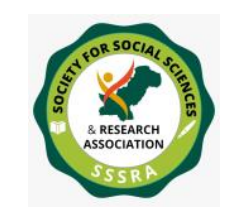

Pak. Journal of Int'L Affairs, Vol 4, Issue 4 (2021) $\quad$ Evaluating the Impact of Policy Certainty ...

during the wars of Afghanistan and Iraq, the US media mainly remained subservient to the ruling class (Hammond, 2007; Lynch and McGoldrick, 2012). Hence, there exists friendly relationship between [western] media and government[s] on policy issues, especially during conflict/war, which reportedly turned into hostility when it [war] causes human casualties. For example, the U.S media, initially, supported the government's policy about Gulf war (1991), however the relationship between the two- media and governmentbecame antagonistic after the compound bombing of the Amiriya air attack shelter, causing a large-scale human casualty (Hallin, 2005). This incident provided media an opportunity to report the Gulf war more independently, focusing on human's sufferings and criticized the U.S officials for carrying out the attack on shelters. In such circumstances, the war reporters presented the challenging perspectives of Gulf war, hence they generated critical opinions, questioning the U.S officials' decisions about the war in Iraq (Althaus at el., 1996).

Contrary to Iraq and other Gulf countries, Afghanistan has witnessed wars from decades, leaving people of Afghanistan to suffer in every aspect of their life- ranging from economic, social, and political to more psychological perspective (Panter, 2012). From the era of Alexander to the Soviet Union strikes Afghanistan on December 24, 1979 (Sallee, 2018) and the U.S forces attacks, casualties have been reported, almost every day, which resulted in compelling the people of Afghanistan to live as refugees in different countries including Pakistan and Iran (Goodson, 2011). Afghanistan, which is officially known as Islamic Republic of Afghanistan, has been remained a center of conflicts since the USSR intervention in 1979 (Barber, 1979). The country, which remained in controlled of Taliban in the 1990 decade, was attacked by the U.S and its allies on October 07, 2001 as a result of the 9/11 attacks in the United States (Maggio, 2007).

Previous studies on the wars in Afghanistan have mainly been focused on the USSR aggression (Stabile, C. A., \& Kumar, D.,2005; Downing, J. D. ,1988), the emergence of Taliban, who came in power to turn the country's politics into Islamic system of government (Fahmy, S.,2004; Malinkina, O. V., \& McLeod, D. M.,2000), the U.S attack on Afghanistan, aiming at curbing Talibanization and terrorism, which was a fallout of the 9/11 attacks in the United States (Nord, L. W., \& Strömbäck, J., 2006). Unlike the above studies, some researchers have focused on peace journalism practices while studying the media coverage of wars in Afghanistan including Hussain, S., 2016; Ottosen, R., 2005 \& 2010.

This study investigates the media framing of the current political situation in Afghanistan after the U.S and its allies' withdrawal, focusing on the context of policy matter for Afghanistan, the U.S and, even, Pakistan, which is one of the important neighboring countries of the war-affected Afghanistan. The researchers examine the nature 




Pak. Journal of Int'L Affairs, Vol 4, Issue 4 (2021)

Evaluating the Impact of Policy Certainty ...

of media coverage on the issues of U.S withdrawal from Afghanistan and re-emergence of Taliban in light of the key arguments of Jamal and Hussain (2021), who argue that the nature of policy issues/war i.e. issue at home and issue at distance- determine the nature of media coverage. They, further, argue that the nature of involvement [in conflict/war] can be classified into two types- indirect and direct. In case of the changing [political] environment in Afghanistan, though the U.S involvement is direct in its nature but its media report Afghanistan's crisis as 'the issue at distance'. Unlikely the U.S, though there is no direct involvement of Pakistan in the U.S decision of withdrawal but being a neighboring country Pakistani media report the Afghanistan's crisis as 'the issue at home' as it has potential impacts on Pakistan's regional policy. However, the Afghan media deal with 'the issue at home' having direct impact on its country and citizens.

The researchers while analyzing the nature of media coverage of the U.S forces' withdrawal from Afghanistan and re-birth of Taliban, selected three newspapers, each from Afghanistan, Pakistan and the U.S. i.e. Outlook Afghanistan, The News and New York Times. The selection of newspapers is made on the basis of their nature and position in their respective countries. For instance, daily Outlook Afghanistan, which was founded by Hussain Yasa in 2004, is the country's first independent English newspaper (Jawad, 2013). The paper, which is published by Afghanistan Group of Newspapers, has a readership of 10,000 and it covers national and international news.

The selection of daily The News is made in the context of Pakistan, which is the largest daily English newspaper of the country, owned by Jang Group of Newspapers. The paper was founded on February 11, 1991 and it is, simultaneously, publishing from Karachi, Islamabad and United Kingdom (Malik, S., \& Iqbal, Z.,2010).). The group also publishes an Urdu language newspaper- daily Jang and holds ownership of private TV channel- Geo News. The media group, especially its English language newspaper- The News, has its influence on policy issues in the country (Jan, M., 2013).

The New York Times is a New York City-based daily newspaper that has long served as the official newspaper of the United States and one of the world's leading newspapers. It was founded in 1851 with a goal to avoid un-professionalism and to report every story in accordance to ethical and professional standards (Davis, E., 1921).

In 1896 Adolph Simon bought the newspapers amid of poor economic condition of the newspaper, who transformed the newspaper into a global renowned newspaper by adopting new technologies to make its publication distinctive, hence it launched an online edition in the year 1995 and a color photography edition in 1997 (Greer, J., \& Mensing, D. ,2006). 


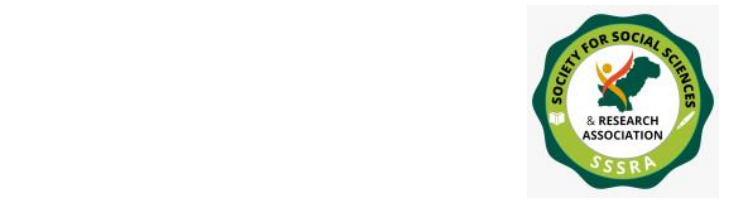

Pak. Journal of Int'L Affairs, Vol 4, Issue 4 (2021)

Evaluating the Impact of Policy Certainty ...

\section{Media-Government Relations in The Context of Policy Issues}

Most of the available literature indicates that the media relations towards government have been studied by different scholars including Bennett, 1990; Bennett \& Lawrence, 1995; Entman, 1991; Hallin, 1986; Herman \& Chomsky, 1988; Robinson, 2017 and Zollman, 2015, reportedly high, in the policy perspectives. Two perspectives i.e. media conformity and criticism dominate the debate on media role in shaping policy or otherwise following policy guidelines in media coverage. The critical media coverage, which has its impact on policy issue[s], is subject to the prevailing environment. For instance, if dramatic but troubling events occur, causing human causalities, the media will report them independently and, hence, fostering the critical narrative (Bennett \& Lawrence, 1995; Lawrence, 2000). However, the media critics such as Herman and Chomsky (1988) view the media as "obedient [actor] to the government" arguing that this state of media is a result of some of the factors including commonality of interests, advertisement and trust on official sources [for getting and/or verifying the information].

Considering the above two perspectives, the available scholarship, mainly, discusses the power of [political and/or military] elites, who put their influences to control the media at the time of war/conflict. In this connection the scholarly work of Daniel Hallin, 1986; Robinson, 2017; Herman and Noam Chomsky, 1988 and Lance Bennett, 1990, is not only questioning the media independence but also explaining some of the conditions that provide media an opportunity to play its role independently. For example, Hallin (1988) argued that media cover the policy issues, especially conflict/war in the broader range of consensus, putting an example of the Vietnam war he found that the supportive coverage of the U.S. government, mainly, fall in the broader sphere of consensus, which attracted major share of media coverage of the Vietnam war. unlike the supportive coverage, the critical coverage is, usually, framed at the time when elites fail to continue their control over media or occurs some of the troublesome events during conflict such as the compound bombing of the Amiriya air attack during Gulf war (Hallin, 2005). This incident, which caused a large number of human casualties, triggered critical/ oppositional coverage of the U.S government.

\section{Policy Uncertainty Regarding the U.S Withdrawal from Afghanistan}

The U.S policy towards Afghanistan shows that there has been prevailed policy uncertainty on the issue of the U.S forces' withdrawal from Afghanistan. From Bonn conference, held on December 05, 2001 to decide the political future of Afghanistan (Maley, W.,2008) to the recent withdrawal of the U.S forces from Afghanistan, the world's political plavers. especially the U.S remained uncertain about the future of Afghanistan, 


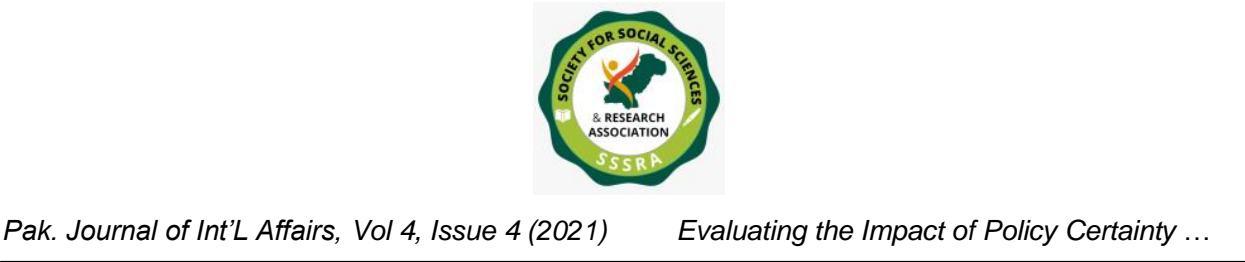

even they were, reportedly, found uncertain about the troops' formal withdrawal. A decade later of the Bonn conference, the Taliban were allowed to open their office in Doha Qatar (Behuria et al., 2019) to facilitate dialogue with the U.S and other international bodies, however later on the peace talks were cancelled as the Taliban accused the U.S of not fulfilling their promises (Reuters, 2019).

Prior to the recent withdrawal, the then U.S president Donald trump announced the withdrawal of half the U.S forces from Afghanistan on December 19, 2018. At the same time, he ordered a complete withdrawal of the U.S forces from Syria as well. However, it was argued that if America leaves Afghanistan they will lose their credibility and there would also be constant threats of Afghan militants (James D., Jason H. et al, 2019). In this uncertain policy circumstances, when the U.S formally decided to call back its troops from Afghanistan, another uncertain factor emerged- relating to the internal security of Afghanistan. Clarifying its position, the U.S reiterated that it will continue air striking in Afghanistan till the exit of foreign forces as the Taliban continue to take hold (CNBC, July 27, 2021) to help the Afghan government in handling with the issue of re-emergence of Taliban.

However, the U.S was reportedly failed to help the Afghan government, leaving it on ground to fight with Taliban. VOA (July 11, 2021) reported that "the U.S [officials] have concerns as the Taliban are advancing after the withdrawal of NATO". Pentagon spokesman John Kirby said that it is now the responsibility of Afghan government to defend themselves from Taliban, who claimed $85 \%$ control of the country. This article examines the media coverage of the U.S withdrawal from Afghanistan and re-emergence to Taliban, theoretically, in the context of policy-media interaction model (Robinson, 2000, 2017), where it is argued the policy uncertainty triggers critical coverage of conflict/ war or any other policy issue. In light of the above discussion this study attempts to answer the following research questions and to test the given hypotheses;

R.Q.1: What are the dominant frames about Taliban after the U.S. withdrawal from Afghanistan?

R.Q.2: What is the media's approach towards the U.S. withdrawal from Afghanistan?

\section{Research Hypothesis}

H1. Pakistani media reportedly covered the issue of the U.S. withdrawal from Afghanistan and re-emergence of Taliban in more objective manner as compare with the U.S. and Afghan media.

H2. Elites' debate dominated the news coverage on the issue of withdrawal and reemergence of Taliban in the selected newspapers.

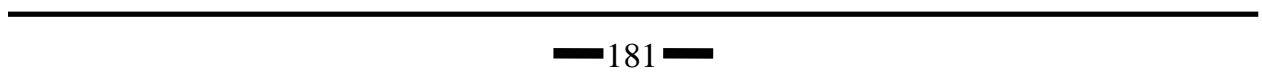




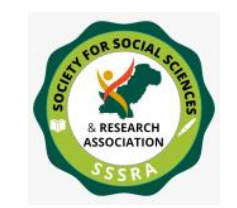

Pak. Journal of Int'L Affairs, Vol 4, Issue 4 (2021)

Evaluating the Impact of Policy Certainty ...

\section{Research Methodology}

The researchers conducted content analysis of three selected newspapers of Afghanistan, Pakistan and the U.S. i.e. Outlook Afghanistan, The News and New York Times to examine the government and media relations in perspectives of the U.S withdrawal and re-emergence of Talibanization in Afghanistan. Timeframe of the study span from June 01 to August 31, 2021, covering the U.S withdrawal from Afghanistan and the issue of re-emergence of Talibanization in the country. Using census sampling technique for data collection, the researchers collected total 195 news stories that were published on front, back and international pages of all three selected newspapers on both issues. To investigate the media and government relationship in the context of selected issues of this study [the U.S withdrawal and re-emergence of Talibanization] the researchers identified total seven frames including withdrawal, criticism on the evacuation, Taliban threat, captured/under siege, insurgents, instability and role of international community. Frames help researchers to get the core message and a clear image of issues (Gamson and Modigliani, 1989), providing clarity to determine the nature of media coverage i.e. supportive, critical or balance/neutral (Entman, 2007).

A coding sheet was designed, which helped researchers to examine the nature of media coverage, and hence determine the media and government relationship on the basis of coverage. To measure the level of agreement on the coding process, the researchers trained two independent coders, having MPhil qualification, and gave them a task to code 30 news stories, 15 each on the issue of U.S withdrawal and re-emergence of Talibanization. The principal author, himself, coded the same news stories. At first attempt both the author and independent coders, the inter-coder reliability was tested, where the Cronbach's alpha was calculated $\alpha=0.81$ for slant categories and $\alpha=0.92$ for frames categories.

\section{Findings and Discussion}

Table 5.1. Cross tabulation of selected issues and the issue of certainty

\begin{tabular}{lcccc}
\hline & & We-emergence of & Total \\
\hline & Certainty & $16(18 \%)$ & $02(2 \%)$ & $18(9 \%)$ \\
Issue of certainty & Uncertainty & $\mathbf{7 1 ( 8 2 \% )}$ & $\mathbf{1 0 6}(\mathbf{9 8 \%})$ & $\mathbf{1 7 7 ( 9 1 \% )}$ \\
Total & & $87(100)$ & $108(100)$ & $195(100)$ \\
$\mathrm{X}^{2}(1, N=195)=15.73, p<0.01$ & & & \\
\hline
\end{tabular}






The above table 5.1 indicates the media coverage of the Afghanistan recent crisis in the context of policy certainty (Robinson, 2000), whereas the findings show that the selected newspapers belong to Afghanistan, Pakistan and the U.S. have framed the issue of the U.S withdrawal from Afghanistan and, following, the re-emergence of Taliban more in the perspective of policy uncertainty i.e. $91 \%$.

Separately, the results as shown in above table, indicate that the issue of the U.S withdrawal from Afghanistan is more reported in the context of policy uncertainty (82\%) while the selected newspapers framed/reported the issue of withdrawal $18 \%$ in term of policy certainty. Similarly, the issue of re-emergence of Taliban in the selected newspapers is reported more uncertain i.e. (98\%) and there was only a little certainty reported in the selected newspapers of three different countries including Pakistan, Afghanistan and U.S i.e. $(02 \%)$.

Statistically, there is a significant difference in the distribution of the selected issues $\left(\mathrm{X}^{2}(1, N=195)=15.73, p<0.01\right)$. These statistical findings show that there exists, mostly, the antagonistic relationship between media coverage and government[s] on the basis of policy certainty [certainty and uncertainty] as advocated by Pier Robinson (2000, 2017).

Table 5.2. Cross tabulation of selected issues and nature of violence

\begin{tabular}{lllll}
\hline & & Withdrawal & $\begin{array}{l}\text { Re-emergence } \\
\text { of Taliban }\end{array}$ & Total \\
\hline \multirow{2}{*}{ Nature of violence } & Violent & $29(33 \%)$ & $\mathbf{6 7}(\mathbf{6 2 \%})$ & $96(49 \%)$ \\
Total & Non-violent & $\mathbf{5 8}(\mathbf{6 7 \%})$ & $41(38 \%)$ & $99(51 \%)$ \\
$\mathrm{X}^{2}(1, N=195)=15.88, p<0.01$ & $87(100)$ & $108(100)$ & $195(100)$ \\
\hline
\end{tabular}

Table 5.2 illustrate the nature of violence in the selected newspapers in terms of the two issues i.e. the U.S forces' withdrawal and re-emergence of Taliban. There is a significant difference in the distribution of the selected issues, statistically, in term of nature of violence i.e. $\mathrm{X}^{2}(1, N=195)=15.88, p<0.01$. These statistical findings show that there exists the relationship between media coverage and nature of violence [violent and non-violent] that determine the nature of relationship between media and government.

The above table shows that the selected newspapers have covered/ framed the selected issues i.e. the U.S forces withdrawal from Afghanistan and the re-emergence of Taliban in the perspectives of violence and non-violence scenario. All of the three selected newspapers from three different countries indicate a total of (49\%) violence and $(51 \%)$ 
non-violence. Individually the U.S forces' withdrawal was reported more in terms of nonviolence i.e. (67\%) while re-emergence of Taliban is reported i.e. (38\%). Similarly, reemergence of Taliban was reported more in terms of violence i.e. (62\%) while the U.S forces' withdrawal was reported i.e. (38\%) in terms of violence.

Table 5.3. Cross tabulation of issues and the nature of media coverage [slants] by selected newspapers

\begin{tabular}{lllll}
\hline & Supportive & Neutral & Oppositional & Total \\
\hline Withdrawal & $\mathbf{3 1}(\mathbf{5 8 \%})$ & $34(47 \%)$ & $22(32 \%)$ & $87(45 \%)$ \\
$\begin{array}{l}\text { Re-emergence } \\
\text { of Taliban }\end{array}$ & $22(42 \%)$ & $\mathbf{3 9}(\mathbf{5 3 \%})$ & $\mathbf{4 7}(\mathbf{6 8 \%})$ & $108(55 \%)$ \\
& $53(100)$ & $73(100)$ & $69(100)$ & $195(100)$ \\
$\mathrm{X}^{2}(2, N=195)=08.77, p=0.02$ & & & \\
\hline
\end{tabular}

Table 5.3 shows the nature of media coverage of the selected issues i.e. the U.S forces' withdrawal and re-emergence of Taliban. The finding shows that the selected newspapers, mostly, covered the issue of withdrawal from Afghanistan highly supportive i.e. $58 \%$, which is followed by the supportive coverage of re-emergence of Taliban (42\%). The neutral category, mainly, dominates by re-emergence of Taliban i.e. 53\%, followed by the issue of withdrawal, which the selected newspapers framed $47 \%$ neutrally. However, the oppositional coverage is, comparatively, triggered high in the context of re-emergence of Taliban i.e. $68 \%$ while the remaining oppositional/critical coverage is given to the issue of the U.S withdrawal from Afghanistan.

Statistically, there is a significant difference in the distribution of the slant categories i.e. $\mathrm{X}^{2}(2, N=195)=08.77, p<0.03$, which shows that there exists the substantial relationship between media coverage [slants] and the selected issues [the U.S withdrawal and re-emergence of Taliban] 


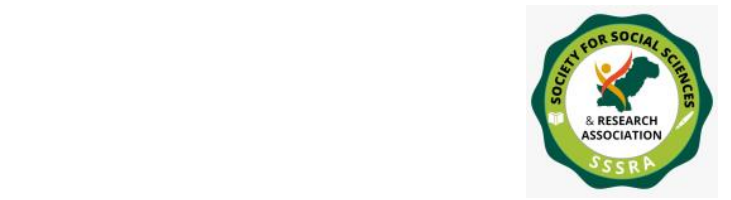

Pak. Journal of Int'L Affairs, Vol 4, Issue 4 (2021)

Evaluating the Impact of Policy Certainty ...

Table 5.4 Cross tabulation of the selected issue

\begin{tabular}{lcc}
\hline Frames & Withdrawal & $\begin{array}{c}\text { Re-emergence of } \\
\text { Taliban }\end{array}$ \\
\hline Withdrawal & $\mathbf{1 8}(\mathbf{2 2 \%})$ & $0(00 \%)$ \\
Criticism on the evacuation & $17(19 \%)$ & $1(01 \%)$ \\
Taliban threat & $5(6 \%)$ & $18(17 \%)$ \\
Captured/under siege & $1(01 \%)$ & $14(13 \%)$ \\
Insurgents & $2(02 \%)$ & $12(11 \%)$ \\
Instability & $\mathbf{2 9}(\mathbf{3 3 \%})$ & $\mathbf{3 7 ( 3 4 \% )}$ \\
Role of International Community & $15(17 \%)$ & $\mathbf{2 6}(\mathbf{2 4 \%})$ \\
Total & $87(100)$ & $108(100)$ \\
\multicolumn{1}{c}{$\mathrm{X}^{2}(6, N=195)=60.47, p<0.01$} & & \\
\hline
\end{tabular}

The above table 5.6 shows the cross tabulation of issues of withdrawal and reemergence of Taliban in the context of selected frames of this study. The overall coverage of the Afghanistan crisis in the selected newspapers after the U.S withdrawal show that, comparatively, more focus is given by the press of Afghanistan, Pakistan and the U.S to the issue of instability, which is framed $33 \%$ in the context of withdrawal and $34 \%$ in the perspective of re-emergence of Taliban in Afghanistan.

The issue of the U.S forces' withdrawal from Afghanistan has been reported in 87 news stories out of total 195 news stories, which have collectively reported by the selected newspapers. Out of the total 87 news stories $22 \%$ were published, specifically, on the broader term of withdrawal, followed $19 \%$ stories that were framed in criticism of the evacuation process while $17 \%$ coverage on the issue of withdrawal sought the role of international community in maintaining peace in the restive country- Afghanistan. The rest of frames such Taliban threat, insurgents and captured got minimum space in all selected newspapers in the context of the issue of withdrawal.

Likewise, the issue of withdrawal, the issue re-emergence of Taliban has also been framed high in the context of instability i.e. $34 \%$, followed by the role of International community, which was framed $24 \%$ by all the three selected newspapers, seeking the role of international players in normalizing the [political] situation in Afghanistan. However, unlike the issue of withdrawal, the issue of re-emergence of Taliban was linked with other frames such as Taliban threat (17\%), captured (13\%) and insurgents $(11 \%)$ that show the influence of Taliban in changing regional politics. 


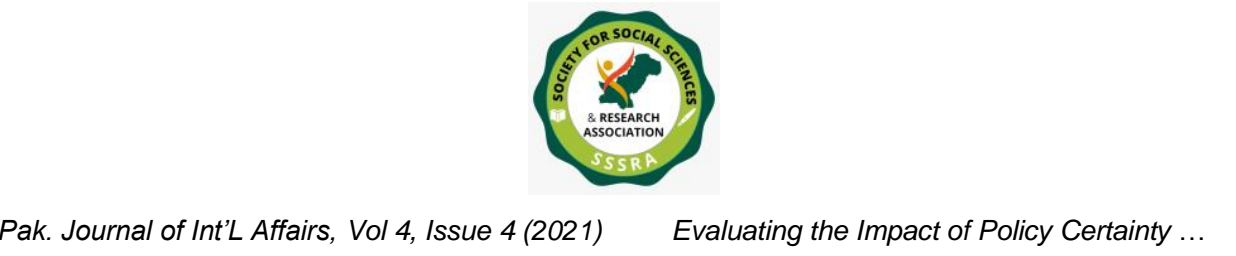

Statistically, there is a significant difference in the distribution of the selected frames in the context of two selected issues i.e. $\mathrm{X}^{2}(6, N=195)=60.47, p<0.01$. These statistical findings show that the selected frames determine the nature of media coverage significantly.

Table 5.5. The cross tabulation of media coverage [slant categories] of the selected issues by newspapers of Afghanistan, U.S and Pakistan

\begin{tabular}{|c|c|c|c|c|c|}
\hline Issues & \multicolumn{2}{|c|}{$\begin{array}{c}\text { Outlook } \\
\text { Afghanistan }\end{array}$} & $\begin{array}{l}\text { The } \\
\text { News }\end{array}$ & $\begin{array}{c}\text { New York } \\
\text { Times } \\
\end{array}$ & Total \\
\hline Withdrawal & \multicolumn{2}{|c|}{$22(31 \%)$} & $27(46 \%)$ & $38(58 \%)$ & $87(45 \%)$ \\
\hline $\begin{array}{l}\text { Re-emergence of } \\
\text { Taliban }\end{array}$ & \multicolumn{2}{|c|}{$49(69 \%)$} & $32(54 \%)$ & $27(42 \%)$ & $108(55 \%)$ \\
\hline Total & \multicolumn{2}{|c|}{$71(100)$} & $59(100)$ & $65(100)$ & $195(100)$ \\
\hline \multicolumn{6}{|c|}{$\mathrm{X}^{2}(2, N=195)=08.34, p<0.02$} \\
\hline Newspapers & \multicolumn{3}{|c|}{ Supportive Neutral oppo } & sitional & Total \\
\hline \multirow{3}{*}{$\begin{array}{l}\text { Outlook Afghanista } \\
\text { The News } \\
\text { New York Times }\end{array}$} & $24(45 \%)$ & \multicolumn{3}{|c|}{ 13(18\%) $\mathbf{3 4 ( 4 9 \% )}$} & $71(37 \%)$ \\
\hline & $10(19 \%)$ & \multicolumn{3}{|c|}{ 43(59\%) 06(09\%) } & $59(30 \%)$ \\
\hline & $19(36 \%)$ & \multicolumn{3}{|c|}{$17(23 \%) \mathbf{2 9}(\mathbf{4 2 \%})$} & $65(33 \%)$ \\
\hline Total & $53(100)$ & \multicolumn{3}{|c|}{ 73(100) 69(100) } & $195(100)$ \\
\hline \multicolumn{5}{|c|}{$\mathrm{X}^{2}(2, N=195)=44.16, p<0.01$} & \\
\hline
\end{tabular}

The first part of the table 5.5 indicates the quantity of coverage in the selected newspapers. Collectively, $45 \%$ stories were published on issue of the U.S forces' withdrawal while 55\% were published on re-emergence of Taliban in the selected newspapers. The newspaper-wise coverage of the issue of the U.S forces' withdrawal and re-emergence of Taliban indicates the Afghanistan and Pakistan have, seemingly, more concern with the issue of re-emergence of Taliban as their media i.e. the Outlook Afghanistan gave 69\% coverage out of its total 71 news stories to the issue of reemergence of Taliban, showing its concern about the re-birth of Talibanization in the country. Likewise, the Pakistani paper- The News also highlighted the issue of reemergence of Taliban higher than the issue of U.S withdrawal as out of its total 59 news 


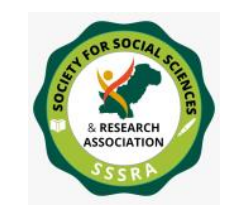

Pak. Journal of Int'L Affairs, Vol 4, Issue 4 (2021) $\quad$ Evaluating the Impact of Policy Certainty ...

stories on both issues, The News gave 54\% coverage to the re-emergence to Taliban in Afghanistan. Unlike the above mentioned two newspapers, the American newspaper- New York Times gave more coverage to the issue of forces' withdrawal as it published $58 \%$ news stories out of its total 65 news on the U.S and its allies' withdrawal from Afghanistan.

Statistically, there is a significant difference in the distribution of news coverage [news stories] being given by the selected newspapers i.e. $\mathrm{X}^{2}(2, N=195)=08.34, p<0.02$. These statistical findings show that there exists the relationship between media coverage and types of issue [withdrawal and re-emergence of Taliban] as the findings show that the U.S newspaper, daily New York Times, gave more coverage to the issue of withdrawal i.e. $58 \%$ of the total coverage that the paper gave to both issues. Contrary, the Outlook Afghanistan and The News gave, comparatively, more coverage to the issue of reemergence of Taliban i.e. $69 \%$ and $54 \%$ respectively.

The second part of table illustrate a significant difference in the distribution of the slant categories i.e. $\mathrm{X}^{2}(2, N=195)=44.16, p<0.01$. These statistical findings show that the selected newspapers covered both the issues in different perspectives that highlight the stances of their respective governments on the issue of withdrawal and re-emergence of Taliban. The findings show that Outlook Afghanistan gave, comparatively, more supportive coverage to Afghan government i.e. $45 \%$ out of the total 53 news stories that were published in all three selected newspapers, followed by New York Times, which published $36 \%$ and The News that published 19\% coverage in favor of Afghan government. In neutral category, Pakistani paper-The News dominates the coverage by publishing 59\% of the total 73 news stories that fall in neutral category. Followed by New York Times (23\%) and Outlook Afghanistan, which published 18\% neutral news stories. Likewise, the supportive category, the oppositional category also dominates by Outlook Afghanistan, which published 49\% news stories out of total 69 news, criticizing the reemergence of Talibanization in Afghanistan. Followed by New York Times, which published $42 \%$ and The News that published $09 \%$ news stories, framing Taliban and their movement critically. 
Evaluating the Impact of Policy Certainty ...

Table 5.6. The nature of media coverage [slants] in term of story actors by the selected newspaper

\begin{tabular}{llllc}
\hline Story & & & & \\
Actors & Supportive & Neutral & Oppositional & Total \\
\hline Taliban & $7(13 \%)$ & $13(18 \%)$ & $\mathbf{3 4}(\mathbf{4 9 \%})$ & $54(28 \%)$ \\
US officials & $\mathbf{2 7}(\mathbf{5 1 \%})$ & $\mathbf{1 8}(\mathbf{2 5 \%})$ & $12(17 \%)$ & $57(29 \%)$ \\
Pakistan officials & $3(5 \%)$ & $13(18 \%)$ & $4(6 \%)$ & $20(10 \%)$ \\
Afghan official & $\mathbf{0 9}(\mathbf{1 7 \%})$ & $4(5 \%)$ & $3(4 \%)$ & $16(08 \%)$ \\
Others & $7(13 \%)$ & $\mathbf{2 5}(\mathbf{3 4 \%})$ & $\mathbf{1 6}(\mathbf{2 3 \%})$ & $48(25 \%)$ \\
& $53(100)$ & $73(100)$ & $69(100)$ & $195(100)$ \\
Total & & & \\
$X^{2}(4, N=195)=38.74, p=0.02$ & & & \\
\hline
\end{tabular}

Table 5.6 illustrate the nature of media coverage in terms of story actor by the selected newspapers. Two actors including Taliban and the U.S officials got prominent space in media coverage as the findings show that the U.S officials were framed high in supportive and neutral categories i.e. $51 \%$ and $25 \%$ respectively while the Taliban were framed, mainly, in oppositional category (49\%), highlighting them as threat to peace in Afghanistan. Statistically, there is a significant difference in the distribution of the story actors, who have their influence in shaping media coverage i.e. $\mathrm{X}^{2}(4, N=195)=38.74$, $p=0.02$ ).

\section{Findings (Testing Research Questions and Hypotheses)}

R.Q.1: What are the dominant frames about Taliban after the U.S. withdrawal from Afghanistan?

The findings of this study suggest that re-emergence of Taliban [Talibanization] has been framed after the U.S withdrawal more in the context of instability in all selected newspapers. The instability frame is dominated by $34 \%$, comparing with the rest of frames i.e. the role of International community (24\%), seeking the role of international players in normalizing the [political] situation in Afghanistan. However, the issue of re-emergence of Taliban was linked with other frames such as Taliban threat (17\%), captured $(13 \%)$ and insurgents $(11 \%)$ that show the influence of Taliban in changing regional politics. These findings (see, table No. 5.4), advise that the subject of Talibanization is covered high in the context of instability by all the three selected newspapers, focusing on the needs for a peaceful solution of the issue/ political crisis in Afghanistan.

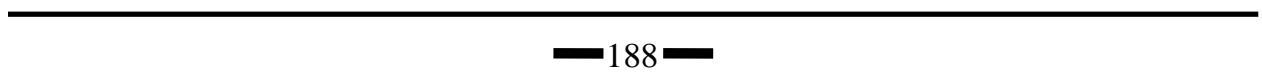




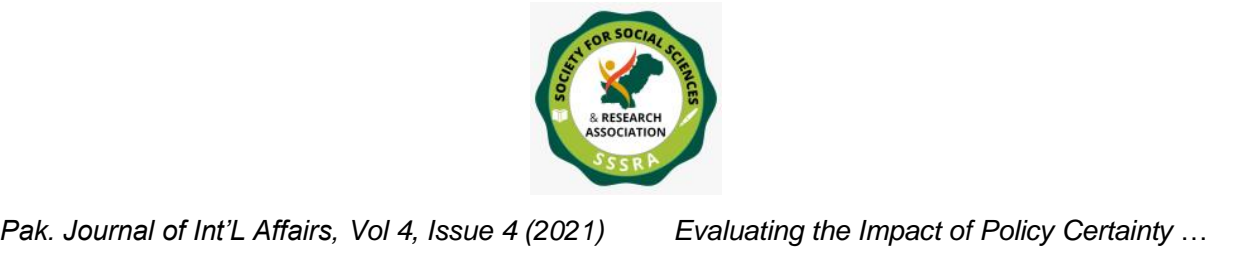

\section{R.Q.2: What is the media's approach towards the U.S. withdrawal from Afghanistan?}

Likewise, the re-emergence of Taliban, the findings suggest that the selected newspapers framed, high, the issue of withdrawal in the context of instability i.e. 33\%. The issue of the U.S forces' withdrawal from Afghanistan has been reported in 87 news stories out of total 195 news stories, which have collectively reported by the selected newspapers. Out of the total 87 news stories $22 \%$ were published, specifically, on the broader term/ frame of withdrawal, followed $19 \%$ stories that were framed in criticism of the evacuation process while $17 \%$ coverage on the issue of withdrawal sought the role of International community in maintaining peace in the restive country- Afghanistan. The rest of frames such Taliban threat, insurgents and captured got minimum space in all selected newspapers in the context of the issue of withdrawal [for reference see table No. 5.4].

The findings illustrate that, in both issues, the selected newspapers were found more inclined towards the issue of instability that caused in the restive-country, Afghanistan after the U.S withdrawal. The current political situation in Afghanistan, where most of the countries of the world including the U.S and, even, Pakistan have, seemingly, failed to adopt a clear policy line, hence their media framed the issue in independent environment that support the key assumption of Pier Robinson (2000) model of policymedia interaction [see table 5.1].

H1. Pakistani media reportedly covered the issue of the U.S. withdrawal from Afghanistan and re-emergence of Taliban in more objective manner as compare with the U.S. and Afghan media.

The findings suggest that the selected newspapers i.e. Outlook Afghanistan, The News, and New York Times covered the issue of the U.S withdrawal from Afghanistan and re-emergence of Taliban in different perspectives. The results indicate that the approach of Pakistani newspaper, more viably, found a 'balance one' as in the case of withdrawal and re-emergence of Taliban the Outlook Afghanistan and New York Times were more supportive to the U.S forces withdrawal, however criticizing the re-emergence of Taliban, but the Pakistani newspaper's stance, in this regard, is found more neutral, reflecting the Pakistan's policy line on the issue of withdrawal and the re-emergence of Taliban (see Table No.5.5, Part-II). The findings confirm the first hypothesis of this study.

H2. Elites' debate dominated the news coverage on the issue of withdrawal and reemergence of Taliban in the selected newspapers.

The findings (see Table No. 5.6) suggest that elites dominate the media coverage on the issue of the U.S withdrawal and re-emergence of Taliban, which [this approach of media] support the key assumption of Bennett (1990) Indexing theory. The findings, 


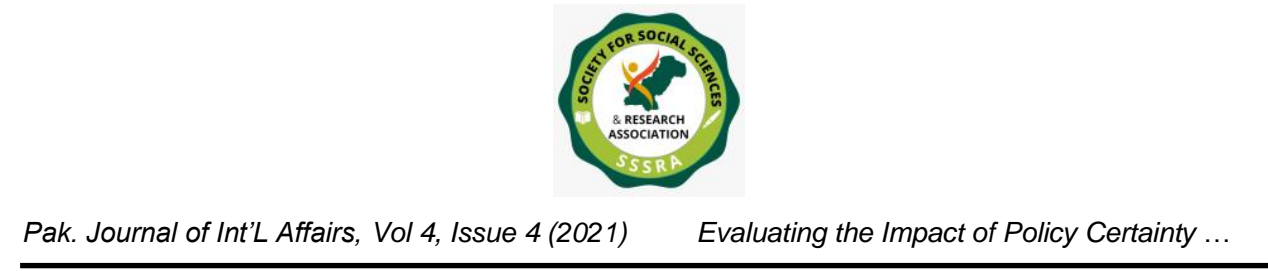

clearly, show that key players i.e. the U.S and Taliban have shaped the elite debate on both issues in media, whereas the U.S dominated 29\% discourse while the Taliban have shaped $28 \%$ overall coverage on the issue of the U.S withdrawal and re-emergence of Taliban. Apart from these key players, Pakistan's officials shaped $10 \%$ overall coverage while Afghan's officials [Ashraf Ghani and his official team] influenced $08 \%$ media coverage in the selected newspapers. However, others including the international communities generated $25 \%$ coverage of the overall coverage being given to both selected issues. Theses finding confirm the second hypothesis of this study.

\section{Conclusion}

This article analyzes the media coverage of the issues of the U.S forces' withdrawal and re-emergence of Taliban or in other word the re-birth of Talibanization in Afghanistan. These issues have their direct impact on Afghanistan and the United States' foreign policy while they have also potentially effected Pakistan's policy in the region. Focusing on the key arguments of Bennett (1990) indexing model regarding the role of elites, arguing that policy debate usually indexes in the range of elites' consensus [for reference see table 5.6] and Robinson (2001) policy-media interaction model that argues that critical media coverage is, mainly, triggered when then there is policy uncertainty. In this study, it is found that majority of the coverage falls in the category of policy uncertainty [for reference see table 5.1]. Hence, this study supports the theoretical arguments of both the models i.e. indexing and media-policy interaction in the context of media coverage of the real time issues- the decision of the U.S government to withdrawal its forces, following the re-emergence to Taliban in Afghanistan. 


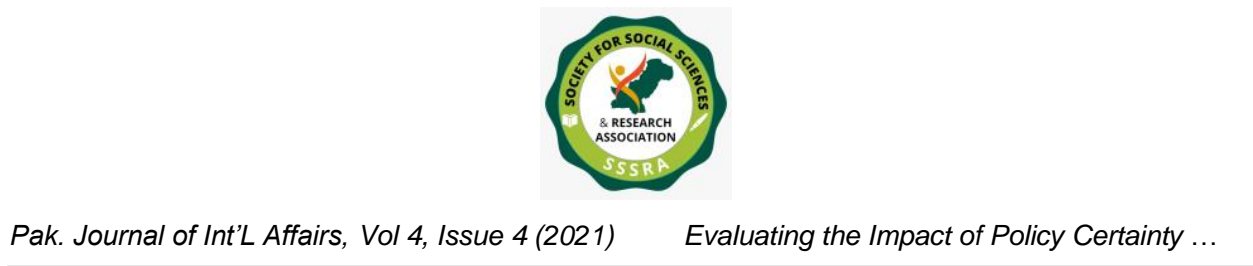

\section{References}

Althaus SL (2003) When news norms collide, follow the lead: New evidence for press

Althaus, S. L., Edy, J. A., Entman, R. M., \& Phalen, P. (1996). Revising the indexing hypothesis:

Amanda, M. (2021) U.S. will conduct airstrikes in Afghanistan against the Taliban as foreign forces withdraw. Available at: https://www.cnbc.com/2021/07/27/usairstrikes-continue-against-the-taliban-amid-troop-withdrawal.html

Banyan. (2012). India-China relations and the media. Available at:

http://www.economist.com/blogs/banyan/2012/05/india-china-relations-and-media

Barber, J. (1979). The Establishment of Intellectual Orthodoxy in the USSR 19281934. Past \& Present, (83), 141-164.

Behuria, A., Hassan, Y. U., \& Saroha, S. (2019). US-Taliban Talks for Afghan Peace:

Bennett, W. L., \& Lawrence, R. G. (1995). News icons and the mainstreaming of social change. Journal of Communication, 45(3), 20-39.

Davis, E. (1921). History of the New York Times 1851-1921.

Din, Jamal Ud \& Shabir Hussain. (2021). "Evaluating the Influence of Policy Certainty and Violence on Coverage of Policy Issues in Pakistani Media" Journal of Peace, Development and Communication, vol. Volume 5, no. Issue 1, 2021, pp. 380-392, https://doi.org/10.36968/JPDC-V05-I01-32

Downing, J. D. (1988). Trouble in the backyard: Soviet media reporting on the Afghanistan

Entman RM (2003) Cascading activation: Contesting the white house's frame after 9/11.

Entman RM (2007) Framing bias: Media in the distribution of power. Journal of

Entman, Robert (1991) 'Framing US Coverage of International News: Contrasts in 


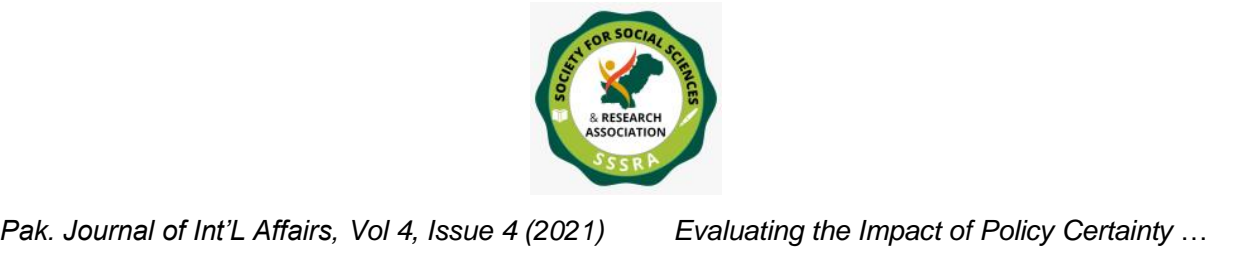

Fahmy, S. (2004). Picturing Afghan women: A content analysis of AP wire photographs during

Gamson, W. A., \& Modigliani, A. (1989). Media discourse and public opinion on nuclear

Goodson, L. P. (2011). Afghanistan's endless war: State failure, regional politics, and the rise of the Taliban. University of Washington Press.

Greer, J., \& Mensing, D. (2006). The evolution of online newspapers: A longitudinal

Hallin DC (1986) The Uncensored War: The Media and Vietnam. Berkeley: University

Hallin, D. (1986) The Uncensored War. New York: Oxford University Press.

Hallin, D. (2005). We keep America on top of the world: Television journalism and the public sphere. Routledge.

Hallin, D. (2005). We keep America on top of the world: Television journalism and theHammond, P. (2007). Media, war and postmodernity. Routledge.Available at: https://www.landlinks.org/country-profile/afghanistan/

Herman ES and Chomsky N (1988) Manufacturing Consent: The Political Economy of the Mass Media. New York: Pantheon.

Hussain S (2016) Media coverage of the Taliban: Is peace journalism the solution? Asia independence. Political Communication 20(3): 381-414.

Izvestia and the New York Times. Journalism \& Mass Communication Quarterly, 77(1), 37-49.

Jan, M. (2013). Print media on coverage of political parties in Pakistan: treatment of Journal, 7(2), 46-56.

Jawad, A. Q. (2013). Media Focus in Afghanistan News Coverage.

Jibran, A. (2019) Afghan Taliban cancel peace talks with U.S. citing 'agenda disagreement'. Available at: https://www.reuters.com/article/us-usa-afghanistantaliban-idUSKCN1P20BL 
Evaluating the Impact of Policy Certainty ...

Ken, B. (2021) Pentagon: US Concerned About Taliban Advances as American Troops Withdraw. Available at: https://www.voanews.com/a/us-afghanistan-troopwithdrawal_pentagon-us-concerned-about-taliban-advances-americantroops/6208127.html

Lawrence R (2000) The Politics of Force: Media and the Construction of Police Brutality. Berkeley: University of California Press.

Lynch J and McGoldrick A (2012) Responses to peace journalism. Journalism: Theory,

Maggio, J. (2007). The presidential rhetoric of terror: The (re) creation of reality immediately after 9/11. Politics \& Policy, 35(4), 810-835.

Maley, W. (2008). Looking Back at the Bonn Process. Afghanistan: Transition Under

Malik, S., \& Iqbal, Z. (2010). Construction of Taliban image in Pakistan: Discourse

Malinkina, O. V., \& McLeod, D. M. (2000). From Afghanistan to Chechnya: News Coverage by

Narratives of the KAL and Iran Air Incidents', Journal of Communication 41(4): 6-27.

Nord, L. W., \& Strömbäck, J. (2006). Reporting more, informing less: A comparison of the Swedish media coverage of September 11 and the wars in Afghanistan and Iraq. Journalism, 7(1), 85-110.

Ottosen, R. (2005). The Norwegian media image of the war in Afghanistan: Peacekeeping or aggression?. Nordicom Review, 26(1), 95-111.

Ottosen, R. (2010). The war in Afghanistan and peace journalism in practice. Media, War \& Conflict, 3(3), 261-278.

Robinson, P. (2000). The policy-media interaction model: Measuring media power during humanitarian crisis. Journal of peace research, 37(5), 613-633.

Robinson, P. (2001). Theorizing the influence of media on world politics: Models of media influence on foreign policy. European Journal of Communication, 16(4), 523-544.

Robinson, P. (2017). The media and foreign policy. In Oxford Research Encyclopedia of Politics. 
Stabile, C. A., \& Kumar, D. (2005). Unveiling imperialism: Media, gender and the war on Afghanistan. Media, Culture \& Society, 27(5), 765-782.

Youngblood S (2012) Professor Komengum: Teaching Peace Journalism and Battling Insanity in Uganda. Unlimited Publishing LLC.

Zollmann F (2015) Bad News from Fallujah. Media, War \& Conflict 8(3): 345-367. 